\title{
ヘドロ化した海域における石炭灰造粒物の 海底散布時のめり込み量の評価と予測 AN EVALUATION AND PREDECTION OF FLY ASH BEANS SINKING MASS INTO THE MUDDY SEDIMENTS
}

\author{
末次弘道 ${ }^{1} \cdot$ 三戸勇吾 ${ }^{2} \cdot$ 木村道夫 ${ }^{3} \cdot$ 日比野忠史 ${ }^{4}$ \\ Hiromichi, SUETSUGU, Yugo MITO, Michio KIMURA and Tadashi HIBINO \\ 1正会員 中国高圧コンクリート工業株式会社環境事業部 （†730-0041 広島市中区小町4-33） \\ 2 正会員 博(農) 復建調査設計株式会社環境技術部水圏環境課（干732-0052 広島市東区光町2-10-11） \\ 3正会員 国土交通省中国地方整備局広島港湾空港技術調査事務所（干730-0029 広島市中区三川町2-10） \\ 4正会員 博 (工) 広島大学准教授 大学院工学研究科 （干739-8527 東広島市鏡山1-4-1）
}

In order to be turned into actual utilization of the coastal environment technique that a muddy sea bed covered with fly ash beans, we evaluated the buried depth of the fly ash beans that generated at the construction in Kaita bay.

The buried depth of fly ash beans occurred $3 \mathrm{~cm}$ to $7 \mathrm{~cm}$. The covering thickness was not contributed to the buried depth. At the construction, fly beans dropped to sea bed $7 \mathrm{~cm}$ at first, after that requisite amount of fly ash beans was dropped. It demonstrated that intrusion to the sediment fly ash beans occur first layer, but the intrusion does not occur above on the second layer.

The buried depth of fly ash beans correlated to the surface water content, and water content of the buried depth sediment was $144 \%$ to $242 \%$. It indicated water content of surface sediment and vertical profile can use predicted buried depth. Additionally we developed simple equipment for predicted the buried depth. It can predict the buried depth by drop the weight sediment core sample and measure the instruction depth of weight.

Key Words : buried depth, fly ash beans, prediction, muddy sediment, water content

\section{1.はじめに}

海域環境の改善手法として覆砂は一定の効果があ ることが認められており有効な対策の一つといえる. しかしながら，近年の瀬戸内海における海砂の採取 禁止や新生堆積物による効果の低減といった問題を 抱えており，これらの課題を解決し得る底質改善手 法の開発が望まれている。

中国地方整備局では，広島湾奥部において，従来 の覆砂の欠点を解決し得る底質改善手法として石炭 灰造粒物によるへドロ被覆手法を提案し ${ }^{1)}$, 平成 22 年 5 月から 6 月にかけて実証試験区画の施工を 実施した。

実証試験で使用した石炭灰造粒物は火力発電所で 発生した石炭灰をセメントで造粒固化した材料であ り，中央粒径は約 $2 \mathrm{~cm}$, 土粒子密度は $1.8 \mathrm{~g} / \mathrm{cm} 3$ 程度, 珪素, アルミニウムを主成分とする他, 鉄, カルシ ウム，マグネシウム分等を含む.

上記の施工では，石炭灰造粒物を海底へ散布する 際に石炭灰造粒物の底泥へのめり込みが生じること が，事前に実施した室内実験より明らかとなってお り, 施工時のめり込み量（材料の割増量）を推定す ることが大きな課題であった。
本稿では，施工終了直後に実施しためり込み量等 に関する調査結果から，へドロ被覆手法施工時にお いて現地で実際に生じためり込み量を評価するとと もに, 今後, 本手法を実用化する上で必要なめり込 みによる割増量の予測方法を考案した.

\section{2. 施エエ法および施エの概要}

（1）実証試験区画の配置および施工層厚

実証試験区画の施工は広島湾奥部に位置する海田

: Measured point of covering thickness and buried depth. Measured point of total application amount.

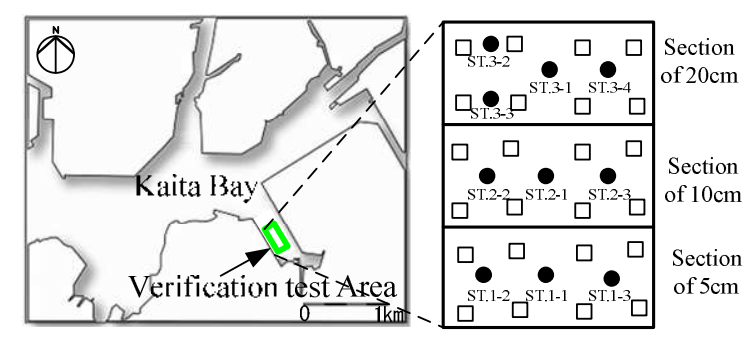

*Station No. of the neasured point of total application amount is nat describer. 図-1 実証試験区画の配置と調査地点. 


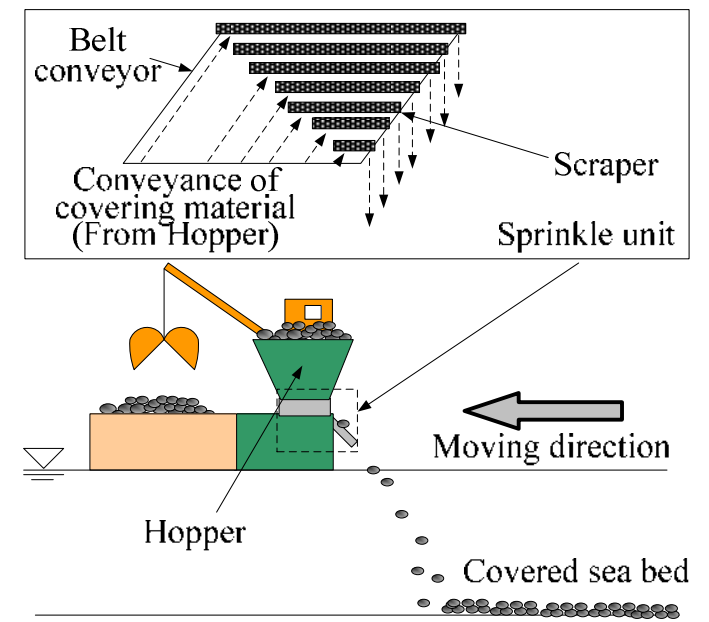

図-2 ベルトコンベア方式薄層撒き出し工法の概念図.

湾南部の奥まった小海域内約6haで行われた（図一 1）。実証試験範囲における水深は7〜 $10 \mathrm{~m}$ であり, 北側から南側にかけて緩やかな傾斜を持つものの, フラットな海底面をしている. 小海域の湾口（北） 側から湾奥（南）側に向けて，20cm，10cm， $5 \mathrm{~cm}$
の厚みを持った区画が設計されており，石炭灰造粒 物による覆砂を実施する上で最適な散布層厚をモニ タリング等で明らかにしていく計画となっている (図-1).

実際の施工に際しては，この設計上の散布層厚に 底泥への石炭灰造粒物のめり込みによる割り増し量 を加えた散布量が必要となる。事前に実施された室 内実験による検討により，実証試験海域で石炭灰造 粒物を散布した場合，最低でも $2 \mathrm{~cm}$ のめり込みによ る割り増しが生じることが予想されていた ${ }^{1)}$ 。そこ で，今回の施工では $2 \mathrm{~cm}$ めり込みによる割り増し 量と考え，それぞれの区画に $2 \mathrm{~cm}$ の散布層厚を加え た散布量を施工上の設計值とした。

\section{（2）施工時期 - 施工工法}

施工は平成22年5月 10 日から平成22年6月 30 日にか けて行われた。施工上の設計散布層厚は $7 \mathrm{~cm}, 12 \mathrm{~cm}$, $22 \mathrm{~cm}$ であるのに対して, 散布する石炭灰像粒物の 中央粒径は約 $2 \mathrm{~cm}$ であり, 薄く均一に材料を散布可 能となる施工工法を用いる必要があった。そこで，

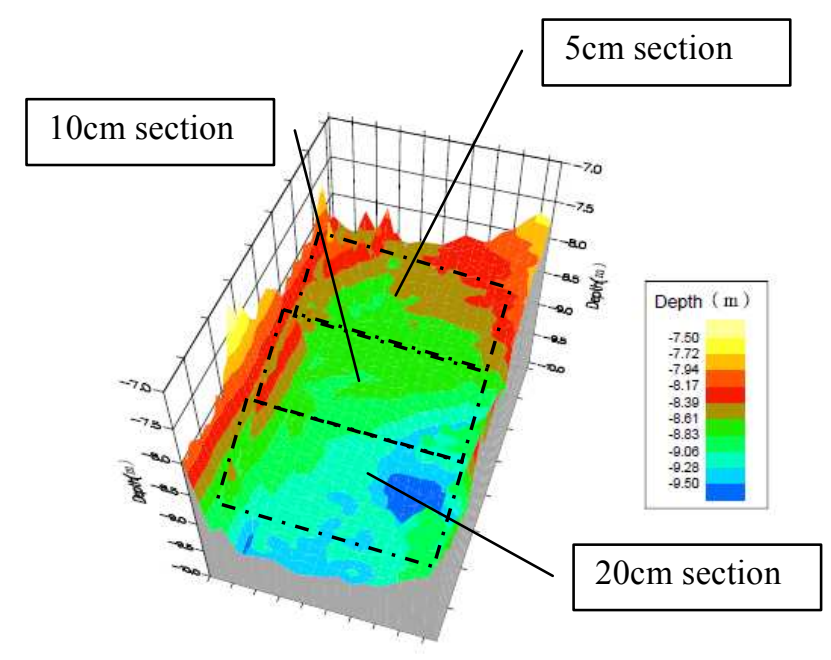

(a) 施工前の海底地形（北側からの鳥瞰図）

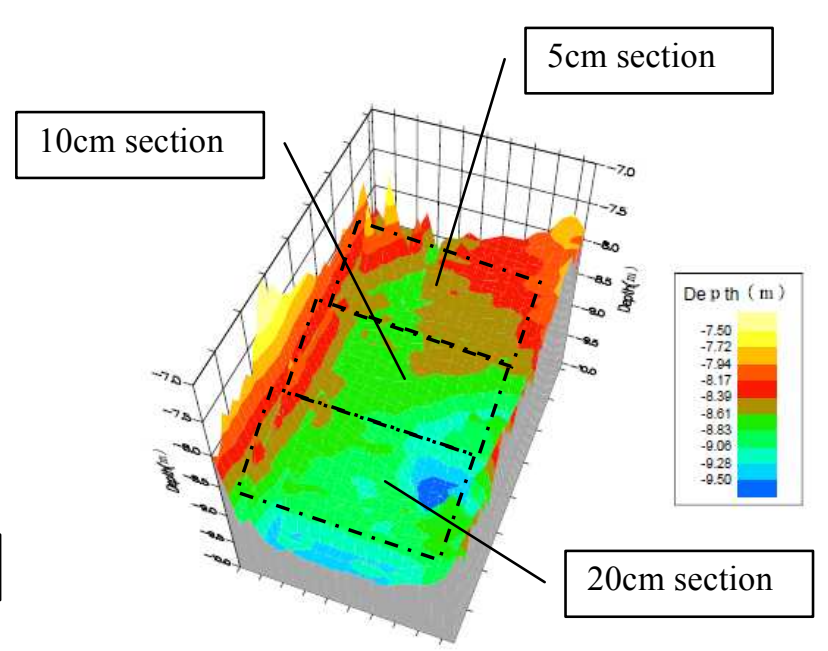

（b）施工後の海底地形（北側からの鳥瞰図）

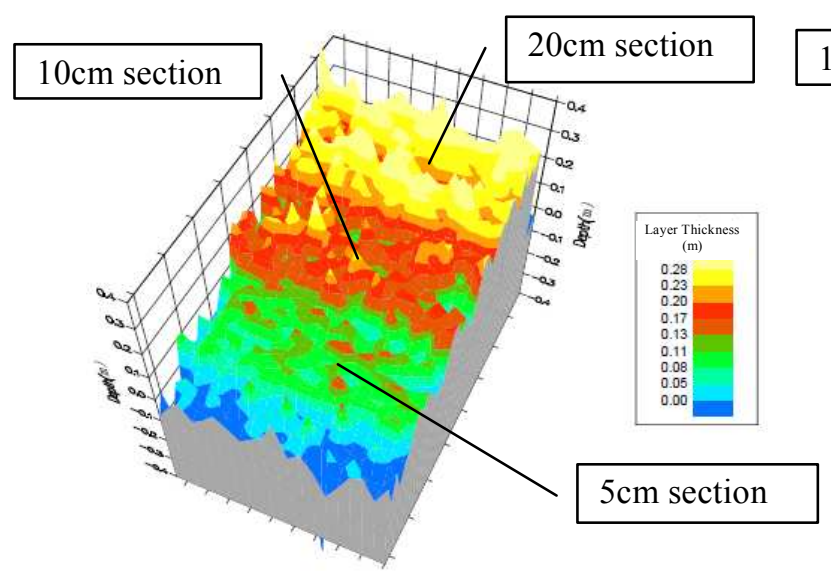

（南側からの鳥瞰図）

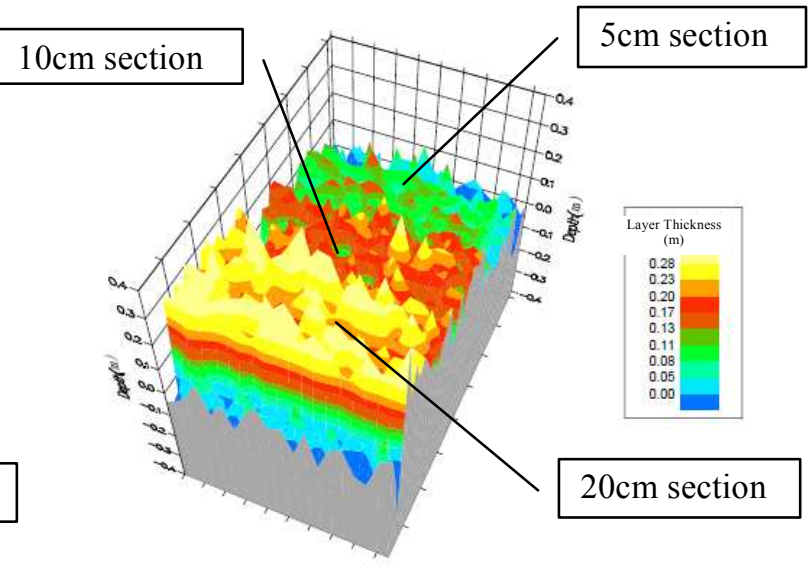

（北側からの鳥瞰図）

（c）実証試験区の形状（b-aより作成）

図-3 実証試験区画の施工状況. 
今回の施工では「ベルトコンベア方式薄層撒出し工 法」が採用された。本手法では，ベルトコンベアを 使用し, ホッパー下部より覆砂材の一定量をベルト コンベアへと供給し，スクレーパーによって均一に 切り出すことで散布を行う ${ }^{2)}$ (図-2) . ベルトコン ベアへの覆砂材の供給量, ベルトコンベアの速度お よび船速を調整することで, 任意の面積当たり散布 量を得ることが可能である. また, 船速はアンカー により船体を固定し, ウインチにてアンカーワイ ヤーを巻き取る速度を制御することで船速が決定さ れる．船速の調整はＧＰＳとコンピュータープログ ラムにより行われる.

施工範囲は東西に分け，それぞれ1工区，2工区と し，1工区については5月19日〜6月3日に，2工区に ついては6月7日〜19日に石炭灰像粒物の散布を行っ た。また, 底泥への石炭灰造粒物のめり込夕量は, 最初に薄層で散布を行なった後に必要な層厚分を散 布することで最小限に留めることが可能である ${ }^{3)}$. そこで， $12 \mathrm{~cm}(10 \mathrm{c} \mathrm{m}$ 区画），22cm（20cm区画） の散布を行う際には, 最初に層厚 $7 \mathrm{~cm}$ 分の石炭灰造 粒物の散布を行い, その後, 必要な層厚分の散布を 行った.

\section{3. 調査方法}

調查は, 施工前後において, 施工区画の形状やめ り込み量の分布を把握するため, 深浅測量, 総散布 量の測定, 砂面棒による被覆層厚の測定, 柱状採泥 試料による被覆層厚およびめり込み量の測定を行っ た. 以下に各調査の方法を示す.

\section{(1) 深浅測量}

区画全体の形状を把握するため，施工前・後にお いて図-1に示寸範囲で深浅測量を行った.

\section{（2）総散布量の測定}

石炭灰造粒物の散布量の精度を確認するため, 総 散布量（めり込み量を含んだ正味の石炭灰造粒物の 散布量）の測定を行った。各試験区画において，施 工前に縦 $30 \mathrm{~cm}$, 横 $30 \mathrm{~cm}$, 高さ $10 \mathrm{~cm}$ の鋼製の受け箱 を図-1の地点に設置した。施工直後に受け箱内に散 布された石炭灰像粒物の層厚を測定することで, 総 散布量を確認した。

\section{（3）砂面棒による被覆層厚の測定}

各試験区画における被覆層厚（めり込み量を除外 した層厚）を把握するため, 砂面棒による被覆層厚 の測定を行った．施工前に図-1に示す地点の海底へ 砂面棒を設置し, 施工後, 砂面棒の值を読み取るこ とで石炭灰造粒物による被覆層厚を測定した。

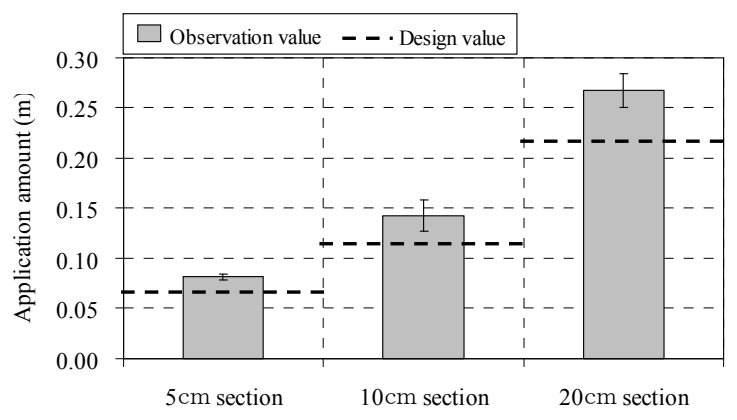

図-4 各試験区における総散布量の測定結果.

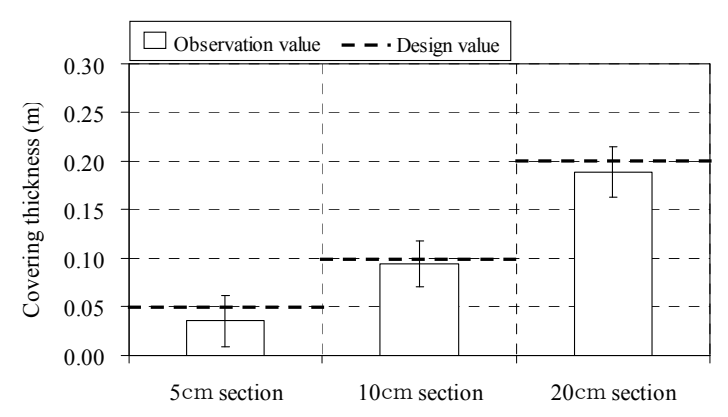

図-5＼cjkstart各試験区における被覆層厚の測定結果.

\section{（4）柱状採泥による被覆層厚・めり込み量の測定}

石炭灰造粒物の被覆層厚やめり込夕量を測定する 上で, アクリルチューブ等による柱状採泥試料の観 察は有効で確実な手法の一つである。しかしながら， 石炭灰造粒物は中央粒径が $2 \mathrm{~cm}$ 程度と粗いため, ア クリルチューブが貫入しにくく, 且つ, 試料が乱れ や寸いため, 施工後に柱状採泥を行うのが困難であ ると考えられた。 そこで, 施工前にアクリルチュー ブ $(\phi=150 \mathrm{~mm}, \mathrm{H}=500 \mathrm{~mm})$ を海底一半分程埋 没させた状態で設置しておき, 施工後にアクリル チューブを回収することで, 限りなく不擋乱に近い 状態で柱状採泥を行った。採取した柱状採泥試料は 上層側から慎重に分取しながら観察を行い, 被覆層 厚とめり込み層厚の測定を行った。

また, めり込み量と底泥の物理的特性の関係を把 握するため, 施工前および施工後において, アクリ ルチューブ設置地点において底泥含水比の測定を 行った.

\section{4. 実証試験区画の施工状況}

施工前および施工後の深浅測量結果の差分から実 証試験区の施工出来高を算定し，区画全体の形状を 把握した（図-3）. $20 \mathrm{~cm}$ 区画， $10 \mathrm{~cm}$ 区画， $5 \mathrm{~cm}$ 区 画の実証試験区は場所によるばらつきが数〜 $10 \mathrm{~cm}$ 程度見られるものの, 概ね設計どおりの形状で施工 されていた。なお，深浅測量の測定結果は測定時の 船の摇動等の影響で $10 \mathrm{~cm}$ 程度の誤差を持つため, $\mathrm{cm}$ 単位での形状の変化を評価することが難しい. しかし, 今回の測定では, 岸壁のコンクリート面等 
表-1 施工前の含水比, めり込み量, めり込み部下層 における含水比.

\begin{tabular}{|c|c|c|c|}
\hline ST. & $\begin{array}{c}\text { Water Content } \\
\text { at 0-2cm }(\%)^{1)}\end{array}$ & $\begin{array}{c}\text { Buried Depth } \\
(\mathrm{cm})\end{array}$ & $\begin{array}{l}\text { Water Content at } \\
\text { Buried Depth }(\%)^{2)}\end{array}$ \\
\hline $1-2$ & 359 & 3.0 & 216 \\
\hline $1-3$ & 470 & 7.0 & 242 \\
\hline $2-2$ & 175 & 3.6 & 216 \\
\hline $2-3$ & 421 & 7.5 & 176 \\
\hline $3-2$ & 447 & 7.0 & 144 \\
\hline $3-3$ & 393 & 4.5 & 217 \\
\hline
\end{tabular}

1)Before the construction. 2)After the construction.

を基準面として，施工前後の測定結果の補正を行っ ており，全体的な形状は概ね把握できていると考え られる。

また，海底に設置した受箱に捕集された総散布量 の平均值について見てみると, 設計值に対する誤差 は $5 \mathrm{~cm}$ 区画では $+1.2 \mathrm{~cm}, 10 \mathrm{~cm}$ 区画では $+2.3 \mathrm{~cm}$, $20 \mathrm{~cm}$ 区画では+4.8cmであった。また，各区画とも に土2cm以下のバラツキ（標準偏差）があった。今 回の施工で散布された石炭灰造粒物の中央粒径は約 $2 \mathrm{~cm}$ でることを考慮すれば，本施工工法は非常に 精度良く材料の散布が行えていたと言える（図-4）。

さらに, 砂面棒および柱状採泥試料による被覆層 厚の測定結果の平均值について見てみると, 設計值 に対する平均值の誤差は $5 \mathrm{~cm}$ 区画では $3.6 \mathrm{~cm}, 10 \mathrm{~cm}$ 区画では $9.5 \mathrm{~cm}, 20 \mathrm{~cm}$ 区画では $18.9 \mathrm{~cm}$ であった

（図-5）。被覆層厚の測定值についても，用いた材 料の粒径を勘案すれば，良い精度で施工されていた と言える。一方で被覆層厚の測定結果の地点間の標 準偏差について見てみると，各区画ともに $2 \mathrm{c} \mathrm{m}$ 以 上と受け箱で測定した全散布量の測定結果よりも大 きくなっていた（図-5）。また, 被覆層厚の設計值 に対する誤差の分布に空間的な偏りは認められな かった。これは 5 章で議論するとおり, 底泥の含水 比によって, 石炭灰造粒物のめり込み量が変化する ことから, 底泥の含水比の分布が比較的不均一で あったことを反映したものと考えられる。

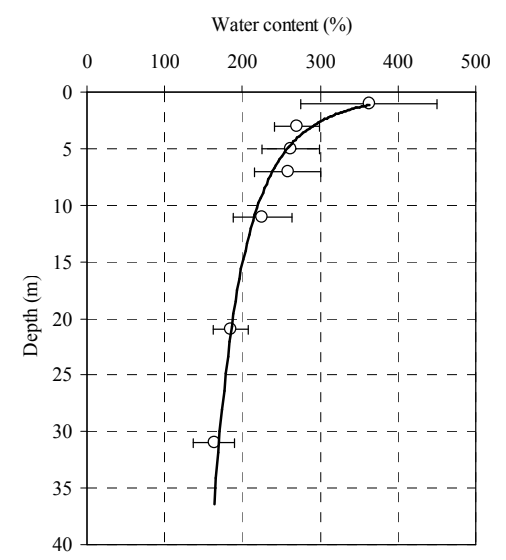

図-6 実証試験海域における平均的な底泥含水比 の鉛直分布.

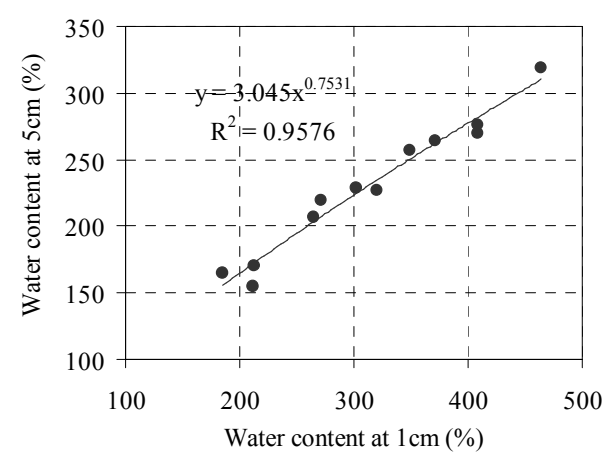

図-7 実証試験海域における深度 $1 \mathrm{c} \mathrm{m}$ と 深度 $5 \mathrm{c} \mathrm{m}$ の底泥含水比の関係.

\section{5. 施工時に生じためり込み量とその予測}

\section{（1）施工時に生じためり込み量}

表-1は今回の施工で得られた表層の含水比とめり 込み量, めり込み部下層-2 c m の含水比を示したも のである。石炭灰造粒物のめり込み量は区画間によ る差は認められず，散布量によってめり込み量に差 は生じなかった（表-1）。これは，2．（2）で示 したとおり, $7 \mathrm{~cm}$ の石炭灰造粒物の散布を行った後 に， $10 \mathrm{~cm}$ 区画では $+5 \mathrm{~cm} の ， 20 \mathrm{~cm}$ 区画では $+15 \mathrm{~cm} の$ 散布を行なったため, 海底面への衝突時の応力が分 散され，7cm散布時以上のめり込みがほとんど生じ なかったためと考えられる。

井上ら（2010） ${ }^{3)}$ は室内実験結果より，施工時に 生じるめり込み量が底泥の含水比によって変化する ことを予測している.今回の実海域での施工結果に ついても，施工前の底泥の表層0-2 $\mathrm{cm}$ の含水比の分 布は, めり込み量の分布と良い一致を見せている

（表-1）.このことは，含水比に代表される海底の 軟弱性がめり込み量を決定づける大きな要因である ことを示している。なお，測定を行った6地点中 1 地 点（ST.2-2）については，含水比が $175 \%$ と相対的 に低いのに対して，めり込み量は $3.6 \mathrm{~cm}$ と相対的に 高く，他の地点と若干傾向が異なっていた。これは， 現地海域の底泥中の含水比の分布が不均一であり， 施工前に含水比を測定した箇所と施工後にめり込み 量を測定した箇所を測定した箇所の含水比が異なっ ていたためと考えられる。

\section{（2）底泥含水比からのめり込み量の予測}

海底泥への材料のめり込み量は材料の割り増し量 を意味するため, 施工計画上、施工前にめり込み量 を予測することが重要となる。井上ら（2010） ${ }^{3)}$ は， 室内実験の結果から, 底泥含水比からめり込み量を 予測する式（1），式（2）を提案している.

$$
\begin{aligned}
& \Delta H / h=\text { const. } \\
& h=0.001\left(W C_{5 \mathrm{~cm}}\right)^{2}-0.25 W C_{5 \mathrm{~cm}}+16.3
\end{aligned}
$$

ここで、 $\Delta H:$ : 込み量 $(\mathrm{cm}), h$ : 含水比が $200 \%$ にる底泥深さ, $W C_{5 \mathrm{~cm}}$ : 深さ $5 \mathrm{~cm}$ の含水比 $\left(W C_{5 \mathrm{~cm}}\right)$ ， const. : 定数 0.41 をそれぞれ示す。 


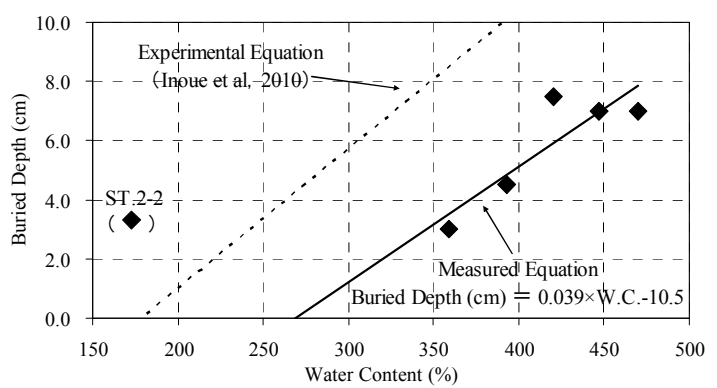

図-8 底泥含水比とめり込み量の関係（試料採取時の 誤差が大きかったST. 2-2は除外して作成）。

式（1）及び（2）は表層から $5 \mathrm{~cm}$ 深度の底泥 含水比からめり込み量を予測している。しかし，実 用上の試料採取の容易さ等を考えれば，表層泥の含 水比からめり込み量を予測できることが簡便である. 実証試験海域で2008〜2009年の間に採取された柱状 採泥試料の含水比のデータは図-6のような分布を持 ち式（3）で示されるように近似される.

$$
W_{z}=a \times Z^{b}
$$

ここで, $W_{Z}$ : 深度 $Z$ の含水比 $(\%), Z:$ 深度 $(\mathrm{cm}), a \cdot b:$ 底泥に固有の定数である.

式(3)の定数 $a, b$ を観測データ毎に求め, 表層か ら $1 \mathrm{~cm}$ 含水比 $\left(W C_{I c m}\right)$ と表層から $5 \mathrm{~cm}$ 含水比 の関係式（4）を得た(図-7). 式（1）（2）及び （4）にて表層 $(1 \mathrm{~cm})$ の含水比からめり込み量の 予測が可能である。

$$
\left(W C_{\text {scm }}\right)=3.045\left(W C_{1 \mathrm{~cm}}\right)^{0.753}
$$

なお，実際には表層から $1 \mathrm{~cm}$ 位置の含水比を正確に 測定するのは困難であり，表層0-2 cm深度を採取し， 深度 $1 \mathrm{~cm}$ の含水比を代表させることが妥当である.

井上ら（2010）による予測式と今回実測した表層 $0-2 \mathrm{~cm}$ 底泥含水比とめり込み量の近似式を比較す ると切片については異なっていたものの，傾きはほ ぼ同程度であった（図-8）。室内実験は縦 $50 \mathrm{~cm}$, 横 $50 \mathrm{~cm}$ ，高さ $100 \mathrm{~cm}$ のアクリル製の筒を用いて行わ れており, 壁面側では衝突時の応力が横に逃げない ため, 実海域よりもめり込み量が多く見積もられて いたと考えられる。しかしながら，今回の実海域で の施工で得られた結果は，室内実験で予測されてい たとおり，底泥の含水比によってめり込み量が予測 できることを示すものであった．

一方で, 式 (4) から, 底泥の含水比の鉛直的な 分布が図-6に示すような累乗曲線で表されるため, 表層の含水比からのめり込み量の予測式が成立した とも言える.すなわち, 今回提示した式は底泥の含 水比の分布が図-6のような分布を持つ場合に適用可 能である. 汎用的に考える上では, 底泥含水比の分 布が不均一である場合も当然考慮すべきである.

表層の含水比に関わらず，めり込み部下層の含水 比は概敞 $200 \%$ 前後である（表-1）。このことは,

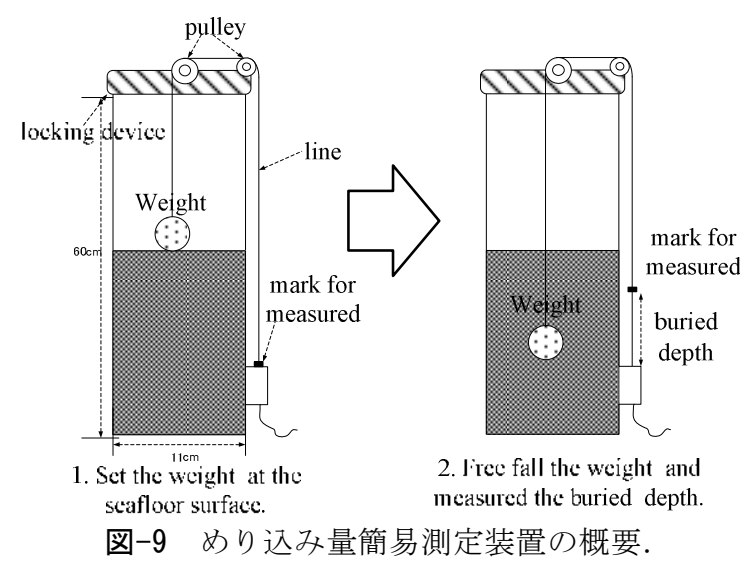

石炭灰造粒物の海底衝突時には，底泥含水比 $200 \%$ 前後の軟度を持つ底泥までめり込むことを示してい る.このことから, 含水比の鉛直的な分布が不均一 な場合には, 式（1）から（4）の予測式は不適当 であり，含水比の鉿直的な分布からめり込みによる 割り増し量を予測することが妥当と考えられる。

\section{（3）簡易な現地測定からのめり込み量の予測}

底泥含水比からのめり込みの予測は, 試料の採 取・含水比の分析と比較的労力がかかる. 可能であ ればより簡易的にめり込み量を予測できることが望 ましい.

そこで，図-9に示すような簡易な装置の開発を試 みた。装置は, 柱状採泥したアクリルチューブ上部 に固定でき, 装置の中央部にある滑車から球状の錘 が下がっている．この錘を柱状採泥試料底泥上の約 $1 \mathrm{~mm}$ の位置に静置した後, 自由落下させ, 石炭灰 造粒物のめり込み量を再現する。錘の重量は石炭灰 造粒物の海底衝突を再現するため, 海底衝突時の運 動エネルギーと同等の位置エネルギーを持つように 調整した。すなわち, 式（5）で表されるエネル ギー保存式に，平均的な中央粒径 $(20 \mathrm{~mm})$ を持つ 石炭灰造粒物の 1 個の重量約 $6 \mathrm{~g}$, 石炭灰造粒物の終 末速度 $55 \mathrm{~cm} / \mathrm{ses}^{3)}$ を適用し, 海底面上 $1 \mathrm{~mm}$ の位置工 ネルギーが石炭灰造粒物の海底衝突時のエネルギー と等しくなる重量を求めた。ここで, 海底面上 $1 \mathrm{~mm}$ 基準としたのは, ヘドロ化した海域では表 層から $1 \mathrm{~mm}$ 程度は浮泥が浮遊した層であり, 海底

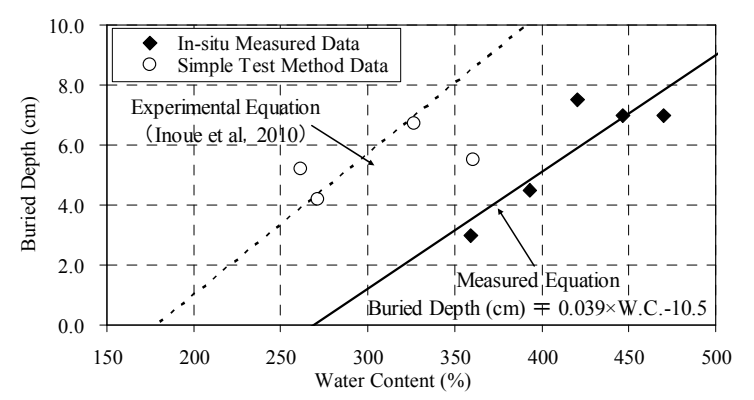

図-10 めり込み量簡易測定装置と海田湾施工時の 底泥含水比とめり込み量の関係。 

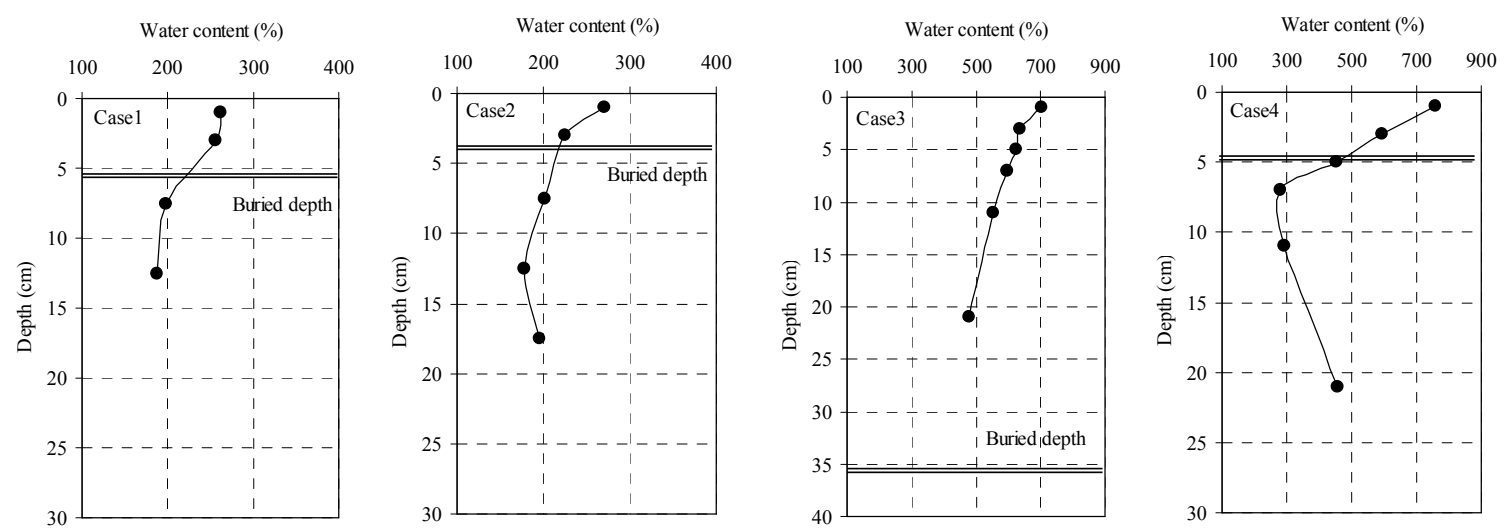

図-11 海底泥における底泥含水比の鉛直分布と簡易めり込み装置の測定值.

面へ設置させ落下させる場合, ほぼ抵抗の無い範囲 であると考えたためである。

$$
\frac{1}{2} \times m_{c} \times v^{2}=m_{c}{ }^{\prime} \times g \times h
$$

ここで、 $m_{c}$ : 石炭灰造粒物 1 個の平均重量 $(\mathrm{g})$, $v$ : 石炭灰造粒物の終末沈降速度 $(\mathrm{cm} / \mathrm{sec}), \quad m_{c}{ }^{\prime}$ : 簡 易めり込み装置の重量 $(\mathrm{g}), \mathrm{g}$ : 重力加速度 $980\left(\mathrm{~cm} / \mathrm{sec}^{2}\right), h$ : 錘の設置高さ $(\mathrm{cm})$ を示す.

図-10は本装置の測定を行った結果と海田湾の施 工で得られた結果を表層含水比との関係で比較した ものである. めり込み簡易測定装置によるめり込み 量の測定值は，概衫室内実験で得られた予測式と一 致していた（図-10）。これはめり込み量簡易測定 装置も室内実験と同様に壁面側では衝突時の応力が 横に逃げないため, 実海域よりもめり込み量が多く 見積もられるためだと考えられる，本装置による石 炭灰造粒物散布時のめり込み量の予測結果は, 数 c $\mathrm{m}$ 程度多めに見積もられるものの, 実用上の簡便さ を考慮すれば，有効な手法であると考えられる．

図-11は底泥含水比の鉛直的な分布が異なる海底 泥におけるめり込み量簡易測定装置の測定結果を示 したものである.Case1，2は実証試験区側の底泥の 測定結果であり，概水含水比 $200 \%$ の深度まで生じ ていることから5。（2）における結論を支持して いる。 また，Case3、4は実証試験区周辺よりもより 有機污濁が顕著で高含水比を持つ底泥を用いた試験 結果である。錘のめり込み深度は概ね含水比 $400 \%$ 程度の深度となっており, めり込み量は含水比のみ ならず泥のコンシステンシー等にも依存することを 示唆している.

\section{7. 結論}

\section{（1）実証試験区のめり込み量の評価}

実証試験区の設計值に対寸る施工出来高の誤差は 数 $\mathrm{cm}$ 程度と精度よく施工ができていた。

底泥一のめり込み量は、3〜 $7 \mathrm{~cm}$ 程度であり、散布層 厚によるめり込み量の違いは明確ではなく, 先に薄層で
散布することで, 散布量の大小に関わらず最小限に留 めることが可能であることと実証された.

また, めり込み量は底泥含水比に依存しており, 室内 実験にて予想されていたとおり, 底泥の含水比が高い ほどめり込み量は多く生じることが明らかとなった。

\section{（2）めり込み量の予測手法の考案}

実証試験区で得られた底泥含水比とめり込み量の関 係から, 表層の含水比を変数とするめり込み量の予測 式を得た. また, めり込みは底泥含水比が $200 \%$ 程度の 深度まで生じていた含水比の鉛直的な分布からめり込 み量の予測を行うことも可能と考えられた。

実用上は, 含水比の鉛直的な分布が不均一である 場合も想定されるため, 代表的な箇所で含水比の鉛直 的な分布を把握した上で, 表層の含水比を変数とした めり込み量の予測式を用いるか, 含水比の鉛直的な分 布から予測するかを判断する必要があると考えられる.

さらに, より簡易的にめり込み量を推定するため, めり 込夕量簡易測定装置を開発した. めり込夕量簡易測定 装置の測定結果は室内実験で得られた予測式と概ね 一致しており，めり込み量の予測に有効であると考えら れる. また, 泥のコンシステンシーといった不確定な 要素も含めて, めり込夕量を推定可能と考えられこ とから，より実用的な手法と考えられる。

今後は本稿で得られた予測手法を他の海域一適用 し，知見を集積することで，予測手法の有効性を確 認していくとともに，予測精度を高めていくことが 重要と考えられる.

\section{参考文献}

1）日比野忠史 -三戸勇吾·今川昌孝·駒井克昭・木村道夫 : ヘドロ被覆設計のための海底有機泥挙動の把握, 海洋 開発論文集，第 26 巻，pp.141-146，2010.

2)中国電力株式会社・株式会社エネルギア・エコ・マテ リア・中国高圧コンクリート工業株式会社。撒き出し 装置. 特開 2008019572. 2008-01-31.

3) 井上省吾・日高和幸・木村道夫 - 日比野忠史 - 首藤 啓 : 石炭灭造粒物の海底散布時の沈降 - めり込夕特性, 海 洋開発論文集, 第 26 巻, pp.129-134, 2010. 